\title{
ランチョンセミナー(8) 深頸部感染症の対処法
}

\author{
司会のことば \\ 市村 恵一 \\ 自治医科大学医学部耳鼻咽喉科学講座
}

菊地 茂教授は患者の立場を理解した上で診療のできる医師である。また、原則は曲げないが、実行の方法にはかな りの柔軟性を持ち合わせている。また義理に厚い、あるいは頼まれたらきちんとやり遂げる人間である。彼は所属医局 では私の後輩にあたるが、一緒に勤務した期間は短い。しかし、上記のような臨床医として好ましい性格を有している ことを感じ取るには十分な期間であった。都会にいると深頸部感染症に出会うことはそれほど多いものではないが、地 方で救急を扱う大規模施設にいると日常的な疾患に変わる。菊地教授の勤務する埼玉県は人口が多い割に耳鼻咽喉科医 数は少なく、しかも救急受け入れ施設が少ないため、いきおい経験数が増える。以上前置きをしたが、菊地教授が本講 演を行うのはまさに適材といえよう。

深頸部感染症は、患者を診たら直ちに診断が下せる（少なくともそれを疑い、検査手段を要領よく適用する）こと、 現にある症状に対して、さらには気道閉塞など起こりうる症状を予測したうえで、迅速、且つ適切に対応することが求 められる病態である。いわば、頭頸部医療の応用問題にあたり、解剖学的知識も動員せねばならない。したがって、こ れができれば耳鼻咽喉科専門医だといっても過言ではないだろう。本疾患は救急疾患であるだけに比較試験が行われに くい。したがって、先人の経験も含めておおよそのコンセンサスはあるものの、個々の問題についてはまだ解決すべき 問題も多数残されている。聴衆の方々には、本講演を聴きながら、問題を抽出して今後の検討材料にする作業も併せて 行っていただき、実りある時間にしていただきたい。 


\title{
深頸部感染症の対処法
}

\author{
菊地茂 \\ 埼玉医科大学総合医療センター耳鼻咽喉科
}

\section{【はじめに】}

媣頸部感染症は頸部の間隙内に生じる感染症の総称で、その中にはリンパ節炎、蜂巣炎、膿瘍が含まれる。抗菌薬が 発達した現在では減少傾向にあるものの、気道狭窄、縦隔炎、敗血症などの重篤な合併症を来しやすいため、適切な対 応を行わないと致死的な状況に陥る可能性がある。したがって、深頸部感染症に対しては正確な診断に基づき、的確か つ迅速な対応が必要である。今回、過去16年間に当科で入院加療を施行した媣頸部感染症114例について解析し、深頸 部感染症の疫学、病態などについて考察するとともに、深頸部感染症およびその合併症の診断、治療を中心に、深頸部 感染症への対処法について述べる。

\section{【当科における深頸部感染症の臨床像】}

1995年 1 月から 2010 年12月までの16年間に埼玉医科大学総合医療センター耳鼻咽喉科で入院加療を施行した深頸部感 染症114例（男性82例、女性32例、平均年齢51.0歳）について検討した（扁桃周囲膿瘍、頸部リンパ節炎は除外）。基礎 疾患は糖尿病が31例と最も多く、以下高血圧症15例、慢性腎不全 3 例、慢性肝炎 3 例などであった。深頸部感染症の原 発部位は口蓋扁桃が最も多く、次いで歯牙、咽頭、唾液腺の順であった。また、感染が進展した間隙では、傍咽頭間隙 が最も多く、次いで顎下間隙、頸動脈間隙、内臓間隙の順であった。膿瘍または蜂巣炎に対して切開・排膿を行った症 例は87例 $(76.3 \%)$ であり、切開・排膿を行わずに穿刺または抗菌薬投与で対応した症例は27例（23.7\%）であった。 なお、全114症例中気管切開術を併施した症例は45例（39.5\%）であった。

\section{【深頸部感染症の診断】}

1. 問診・視診・触診

頸部の腫脹、発赤、圧痛を確認し、その範囲を把握するとともに、感染の原因部位となりうる大唾液腺、歯牙、口沿 底、咽頭後壁、口蓋扁桃など器官、組織の状態をよく観察する。また、気道狭窄は深頸部感染症の最も重篤な合併症の 1つであるため、呼吸困難がなくとも、ファイバースコープにて喉頭蓋、声門部、披裂部などの腫脹による上気道狭窄 がないか、あるいはその危険性が予想される所見があるかどうか、早急に気道確保をすべき状態であるか否かを、初診 時に十分に評価しておく必要がある。また、外傷、異物（魚骨など）、歯科治療の有無、糖尿病の存在など、感染の契 機となるようなエピソードや感染を重症化させる因子がないかも確認しておく。

2. 全身状態の把握

体温、血圧、脈拍数、呼吸回数、 $\mathrm{SpO}_{2}$ などのバイタルサインは初診時に必ず確認する。さらに、血液学的検査（血 算、CRP、血糖、生化学検查など）や、必要に応じて DIC の有無も確認する。

\section{3. 画像診断}

多くの情報を得るには造影 CT が有用である。膿瘍が形成されている場合、膿瘍周囲が造影され、中心部が低吸収域 となる。これに対し、蜂巣炎では軟部組織の浮腫、脂肪組織の閉塞が認められるものの、造影剤による辺縁増強効果が みられないことから、蜂巣炎と膿瘍との鑑別が容易となる。また、造影を施行した場合、総頸動脈や内頸静脈などの大 血管と感染巣との位置関係が明暸に同定できるため、引き続いて頸部の切開および排膿を行う際に、安全かつ効果的な 排膿ルートを決定することができる。また、縦隔の評価のために、胸部も含めて CTにて検索することが望ましい。

4. 細菌学的検查

媣頸部感染症においては好気性菌ではレンサ球菌が、嫌気性菌では Peptostreptococcus、Prevotella などが検出される ことが多く、嫌気ポーターを用いて、閉鎖䏕から嫌気環境下で検体を採取する必要がある。敗血症が疑われる場合には 血液培養も行う。

\section{【深頸部感染症の治療】}

\section{1. 保存的治療}

保存的治療の基本は、起炎菌に対して感受性を有する抗菌薬の全身投与であるが、起炎菌が確定するまでは、empiric therapy としてペニシリン系またはセフェム系抗菌薬を単独またはクリンダマイシンと併用で投与する場合が多いが、 重篤な症例ではカルバペネム系抗菌薬を使用する場合もある。蜂巣炎の段階でとどまっているような症例では、保存的 治療のみで治癒する場合もある。

\section{2. 外科的治療}

膿瘍が限局している場合など、切開せずに穿刺にて対応できる場合もあるが、(1)広範囲または多房性の膿瘍が形成さ れている場合、(2)気道狭窄の恐れがある場合、(3)舌骨下や縦隔に感染が波及している場合、(4)ガス産生が認められる場 合、(5)嫌気性菌の関与が強く疑われる場合、(6)穿刺や抗菌薬の点滴静注で軽快しない場合、(7)異物が原因となっている 場合、(8)筋膜壊死や筋壊死が疑われる場合、(9) DIC にいたる恐れがある場合には外切開の適応と考えている。また、 
気道狭窄を生じている場合に気管切開を施行するのは当然であるが、狭窄がなくても切開排膿後に喉頭浮腫が予見され る場合には気道を確保しておくべきである。

\section{【深頸部感染症の合併症】}

\section{1. 気道狭窄}

上気道への炎症の波及、循環障害による喉頭部の浮腫などにより気道の狭小化が生じ、呼吸困難や喘鳴がみられる時 には、気道の確保が必要となる。

\section{2. 縦隔炎}

縦隔に感染が波及する経路としては、咽後間隙から椎前隙を経て縦隔へ至る経路、頸動脈隙から縦隔へ至る経路、内 臓隙から椎前隙を経て縱隔へ至る経路、前頸隙から縦隔へ至る経路がある。胸部単純 X線撮影では縦隔陰影の拡大が見 られ、CT 撮影では縦隔に膿瘍形成などの所見を認める。

3. 敗血症

重症化した症例や宿主の免疫力の低下している症例で生じやすい。発熱後に、血圧低下、呼吸困難、意識障害などが 出現するときは、急性呼吸促迫症候群（ARDS）や、全身性炎症反応症候群（SIRS）の前兆であることが多いので、特 に注意すべきである。

4. 壊死性筋膜炎

細菌感染に虚血性変化が加わり、筋膜や筋の壊死が生じ、さらに皮虑や皮下組織にも壊死性病変が及ぶ重篤な合併症 である。壊死性降下性縦隔炎に進展しやすい。

5. 血管病変

まれではあるが、頸部大血管の破綻による出血性ショック、内頸静脈血栓症に伴う肺塞栓症も致死的な合併症とな る。 